\title{
CENTRAL MOTOR CONDUCTION IN HUMAN CHRONIC CHAGAS' DISEASE
}

\author{
M.J.SEGURA, O.M.GENOVESE, ELSA SEGURA, OLGA P.SANR, R.E.P.SICA
}

SUMMARY - The possible involvement of spinal alpha motor neurons, dorsal root ganglia and sensory fibers in human chronic Chagas' disease was previously demonstrated. More recently neuropsychological and sensory evoked potentials studies suggest the existence of central nervous system abnormalities in these patients. We assessed the state of central motor pathways in 46 patients with chronic Chagas' disease and 30 healthy volunteers by means of percutaneous cortical and spinal electrical stimulation. No significative slowness in pyramidal tracts(PT) conduction was found when comparing both groups. Neither any individual patient exhibited abnormally delayed PT conduction values beyond the upper normal limit of the healthy volunteers. These results suggest that, in contrast with other neural systems, the large myelinated PT fibers are usually spared in human chronic Chagas' disease.

KEY WORDS: chronic Chagas' disease, central nervous system, motor evoked potentials.

\section{Conduccion motora central en la enfermedad de Chagas cronica humana}

RESUMEN - Estudios previos han demostrado que la enfermedad de Chagas cronica (ECHC) humana puede comprometer las motoneuronas espinales alfa, el ganglio de la raiz dorsal y las fibras sensitivas perifericas. Mas recientemente otras investigaciones han senalado que algunos de estos pacientes presentan anomalias en pruebas cognitivas y de potenciales evocados sensoriales, sugiriendo tambien la existencia de compromiso central en esta entidad. En linea con estos ultimos hallazgos hemos estudiado el estado de la conduccion motora central en 46 pacientes con ECHC y en 30 voluntarios sanos. Para ello se emplearon tecnicas de estimulacion electrica cortical transcraneana y espinal percutanea. No se encontro un enlentecimiento significativo en la conduccion piramidal del grupo con ECHC comparado con los voluntarios sanos. Considerados individualmente, en ningun paciente con ECHC la conduccion corticoespinal presento valores que excedieran el limite superior normal del grupo control. Estos resultados sugieren que a diferencia de lo que ocurre con otros sistemas neurales, las fibras piramidales mielinizadas de grueso calibre se encuentran usualmente indemnes en pacientes con ECHC.

PALAVRAS LLAVE: enfermedad de Chagas cronica, sistema nervioso central, potenciales evocados motores.

Previous investigations have demonstrated that peripheral nervous system involvement frequently occurs in chronic Chagas' disease. When present, this neurological complication mainly targets on alpha motoneurons ${ }^{8,15}$ and on sensory fibers or the dorsal root ganglia ${ }^{16}$, as has been shown in clinic electrophysiological studies. Such results are in agreement with those others found in the animal model during the chronic phase of Trypanozoma cruzi infection. More recent communications focusing on the central nervous system suggest the existence of central conduction abnormalities in sensory pathways ${ }^{1}$ and of cognitive dysfuncion in patients with chronic Chagas' disease $^{5}$. On line with these last findings, the aim of this study was to assess the state of the central motor pathways in patients with chronic Chagas' disease by means of transcranial cortical (TCS) and percutaneous spinal (PSS) stimulation techniques.

Departamento Medicina, Orientacion Neurologia, Facultad de Medicina, Universidade de Buenos Aires. Aceite: 21 setembro 1993.

Dr. Roberto E.P. Sica - Division Neurologia, Hospital J.M.Ramos Mejia - Urquiza 609 - 1221 Buenos Aires Argentina. 


\section{MATERIALS AND METHODS}

Patients. The study involved 46 patients with the diagnosis of chronic Chagas' disease made at the Instituto Nacional de Diagnostico e Investigacion de la Enfermedad de Chagas in Buenos Aires. They were 25 women and 21 men, aged between 17 and 57 years. Coincidental causes of neurological disorders were eliminated by rejecting patients over 60 years and those with history of toxic, metabolic, genetic or parasitic disease know to induce nervous system damage.

Subjects. Thirty healthy volunteers, 12 women and 18 men, aged between 17 and 74 years served as controls.

All patients and subjects gave in formed consent to the procedures. The studies were approved by the local Ethical Committee and by the Steering Committee on Chagas' disease (World Health Organization).

Techniques. Unifocal electrical TCS and PSS were performed employing techniques that had been widely reported elsewhere 26,11-13. Motor Evoked Potentials (MEPs) were elicited by applying isolated transcranial stimuli over the corresponding cortical motor areas with a maximal intensity of $1000 \mathrm{~V}$ and a duration of 75 us each. EMG signals were recorded through surface silver electrodes from the Thenar muscles in all patients, and from the Tibialis anterior muscles in 44 patients, while undergoing a slight voluntary contraction ${ }^{10}$. MEP latencies were obtained by arithmetical averaging 4 to 8 responses in each tanget muscle. The central motor conduction time (CMCT) in the corticocervical segment (CCS) of the pyramidal tracts (PT) was calculated by substracting the peripheral conduction time (PCT) and the corticospinal monosynaptic delay $(0.5 \mathrm{~ms})$ from the MEP latency. To obtain the PCT, F wave calculations $[(\mathrm{F}+\mathrm{M} 1 \mathrm{~ms}) / 2]^{7,11,13}$ or PSS were employed.

\section{RESULTS}

Table 1 shows the MEP and CMCT values obtained from 30 healthy volunteers and 46 patients with chronic Chagas' disease. When pooled, patients values did not show any significant prolongation in MEP latency from controls, either with EMG recordings performed in the upper or the lower limbs. CMCT mean values from patients were also not significantly different from these of healthy subjects. If individually considered, none of the patients disclose MEP or CMCT values beyond the upper limit (mean value plus $2.5 \mathrm{SD}$ ) of the control group.

\section{COMMENTS}

Early studies on the neurological complications of chronic Chagas' disease found in some patients electrophysiological evidence for spinal alpha motoneuron involvement. Those findings rise the question of whether the anterior horn damage was actually primary, either by direct invasion or remote effect of the Trypanozoma cruzi, or perhaps could reflect transynaptic degeneration due to upper motor neuron disease ${ }^{15}$. This study was addressed to investigate the last possibility by assessing the state of central motor conduction by means of TCS. Our results do not show evidence for CMCT abnormalities, suggesting that the PTs are usually spared in chronic human Chagas' disease.

This is in agreement with the results of other authors who failed to find indirect signs of PTs

Table 1. MEP and CMCT values in 30 healthy volunteers and in 46 patients with chronic Chagas' disease

\begin{tabular}{lcc}
\hline & Controls & Patients \\
\hline $\begin{array}{c}\text { MEP latency in the } \\
\text { Thenar muscles }\end{array}$ & $\begin{array}{c}19.41 \pm 0.72 \mathrm{~ms} \\
(\mathrm{n}: 35)\end{array}$ & $\begin{array}{c}18.34 \pm 1.26 \mathrm{~ms} \\
(\mathrm{n}: 46)\end{array}$ \\
$\begin{array}{c}4.79 \pm 0.63 \mathrm{~ms} \\
(\mathrm{n}: 34)\end{array}$ & $\begin{array}{c}4.39 \pm 0.56 \mathrm{~ms} \\
(\mathrm{n}: 44)\end{array}$ \\
$\begin{array}{c}\text { MEP latency in the } \\
\text { Tibialis anterior } \\
\text { muscle }\end{array}$ & $\begin{array}{c}28.86 \pm 0.98 \mathrm{~ms} \\
(\mathrm{n}: 17)\end{array}$ & $\begin{array}{c}24.57 \pm 1.58 \mathrm{~ms} \\
(\mathrm{n}: 44)\end{array}$ \\
\hline
\end{tabular}

MEP, motor evoked potential; CMCT, central motor conduction time; CCS, corticocervical segment. damage employing several methods, like excitability coefficient ${ }^{14}, \mathrm{H}$ reflex recovery curve and silent period studies?. Nevertheless, it could be argued that, despite CMCT measurement is considered a sensible method to evaluate the central motor pathways ${ }^{17}$, it can only assess the conduction properties of the large PTs fibers. The latter only represent less that $2 \%$ of the whole corticospinal tract population ${ }^{3}$. This opens the question about the state of the slow conducting PTs fibers in chronic Chagas' disease. 
Further investigation, directed to detect slight degress of axonal loss in the PTs, will be necessary to get more definitive conclusions regarding this subject.

Acknowledgment- This investigation received financial support from the UNDP/World Bank/Who Special Programme for Research and Training in Tropical Diseases.

\section{REFERENCES}

1. Genovese OM, Sanz OP, Correale J, Garcia Erro M, Sica REP Cerebral evoked potentials in human chronic Chagas' disease. Arq Neuropsiquiatr 1989, 47:274-278.

2. Hassan NF, Rossini PM, Cracco RQ, Cracco JB. Unexposed motor cortex activation by low voltage stimuli. In Morrocutti C, Rizzo PA (eds) Evoked potentials neurophysiological and clinical aspects. Amsterdam: Elsevier, 1985.

3. Lassek AM. The human pyramidal tract: IV. A study of the mature, myelinated fibers of the pyramid. J. Comp. Neurol. 1942, 76: 217-225.

4. Losavio A, Jones MC, Sanz OP, Mirkin G, Gonzalez Cappa SM, Muchnik S, Sica REP. A sequential study of peripheral nervous system involvement in experimental Chagas' disease. Am J Trop Med Hyg, 1989, 41:547-555. 5. Mangone CA, Pereyra SA, Genovese O, Segura E, Sica REP. Neuropsychological impairment in chronic Chagas' disease. Neurology1992, 42,(Supp13): 278.

6. Marsden CD, Merton PA, Morton HB. Percutaneous stimulation of spinal cord and brain: pyramidal tract conduction velocities in man. J Physiol 1982,328:6P.

7. Rossini P, Caramia M, Zarola F. Mechanisms of nervous propagation along central motor pathways: non-invasive evaluation in heal thy subjects and in patients with neurological disease. Neurosurgery 1987, 20:183-191.

8. Sanz OP, Sica REP, Basso S, Fumo T. Compromiso del sistema nervioso periferico en la enfermedad de Chagas cronica. Medicina (Buenos Aires) 1980,40(Suppl 1):231-233.

9. Sanz OP, Sica REP, Fumo T, Basso S. Spinal reflex activity in patients with chronic Chagas' disease. Medicina (Buenos Aires) 1982,42:633-636.

10. Segura MJ, Gandolfo CN, Sica REP. Estimulacion cortical transcraneana en humanos. Medicina (Buenos Aires) 1988, 48:108-109.

11. Segura MJ, Gandolfo CN, Sica REP. Central motor conduction in ischaemic and hemorrhagic cerebral lesions. Electromyogr Clin. Neurophysiol 1990,30:41-45.

12. Segura MJ, Gandolfo CN, Bueri JA, Sica REP. Transcranial stimulation: long-lasting effects on lower motor neuron excitability. Neurology 1990, 40 (Suppl 1): 214.

13. Segura MJ, Gandolfo CN, Sica REP. Electrophysiological assessment of spinal cord lesions by means of transcranial cortical stimulation. Electromyogr Clin Neurophysiol 1992, 32:299-306.

14. Sica REP, Mc Comas AJ, Upton A. Impaired potentiation of $\mathrm{H}$ reflexes in patients with upper motoneuron lesions. J Neurol Neurosurg Psychiatry 1971, 34:712-717.

15. Sica REP, Sanz OP, Aristimuno GG, Basso S, Pagano MA, Taratuto A, Fumo T, Ratusnu AF, Colombi A. Muscle denervation in chronic Chagas' disease. Medicina (Buenos Aires) 1979, 39:579-588.

16. Sica REP, Filipini D, Panizza M, Fumo, T, Baso S, Lazzari J, Molina HA. Involvement of the peripheral sensory nervous system in human chronic Chagas' disease. Medicina (Buenos Aires) 1986, 46:662-668.

17. Thompson PD, Day BL, Rothwell JC, Dick JPR, Cowan JMA, Asselman P, Griffin GB, Sheehy MP, Marsden $\mathrm{CD}$. The interpretation of electromyographic response to electrical stimulation of the motor cortex in diseases of the upper motor neuron. J Neurol Sci 1987, 80:91-110. 